\title{
STRATEGI PIHAK PESANTREN DALAM MENGATASI SANTRI YANG MELAKUKAN PERILAKU MENYIMPANG
}

\author{
Elsa Hoerunnisa, Wilodati, Aceng Kosasih \\ Universitas Pendidikan Indonesia \\ Jl. Dr.Setiabudi 229 Bandung 40154, Jawa Barat, Indonesia \\ E-mail: elsa.hoerunnisa@yahoo.co.id
}

\begin{abstract}
Abstrak Penelitian ini membahas upaya pondok pesantren dalam mengatasi perilaku menyimpang pada santri di pondok pesantren Miftahul Huda III Kelurahan Margabakti Kecamatan Cibeureum Kota Tasikmalaya. Penelitian ini dilatarbelakangi oleh adanya permasalahan perilaku menyimpang yang dilakukan oleh santri di pondok pesantren. perilaku menyimpang tersebut berkaitan dengan pelanggaran-pelanggaran peraturan tata tertib yang telah ditetapkan oleh pesantren. Pesantren sebagai bengkel moral tentunya memiliki peranan penting dalam upaya mengatasi segala bentuk perilaku menyimpang yang terjadi. Penelitian ini bertujuan untuk mengetahui strategi pondok pesantren dalam mengatasi perilaku menyimpang pada santri. Penelitian ini menggunakan pendekatan kualitatif dan metode studi kasus. Pengumpulan data dilakukan dengan teknik observasi, wawancara mendalam, dan studi dokumentasi. Informan penelitian terdiri dari pengurus pondok pesantren, santri laki-laki dan santri perempuan, serta masyarakat sekitar. Hasil penelitian ini menunjukkan bahwa upaya yang dilakukan oleh pondok pesantren dalam mengatasi santri yang berperilaku menyimpang yaitu dengan memberikan teguran, memberikan sanksi dan denda, serta melakukan kerja sama dengan masyarakat. Diharapkan dengan upaya tersebut, santri mampu berperilaku sesuai dengan nilai dan norma yang berlaku agar tercipta kembali kondisi sosial yang tertib.

Kata kunci: $\quad$ perilaku menyimpang, pondok pesantren, santri
\end{abstract}

\section{PENDAHULUAN}

Pada hakikatnya, setiap individu memiliki kecenderungan untuk berperilaku menyimpang. Hal tersebut karena tidak ada manusia yang sepenuhnya patuh pada norma yang berlaku. Seperti halnya yang terjadi pada santri di pondok pesantren. Perilaku menyimpang yang terjadi pada santri merupakan hal yang ironis. Hal tersebut dikarenakan meskipun santri dalam kesehariannya berada di lingkungan pesantren yang mampu memelihara dan melaksanakan norma agama semaksimal mungkin, hidup berdampingan dengan kyai, dididik oleh kyai, dan menekankan pentingnya moral keagamaan, namun tak dapat dipungkiri bahwa tidak sedikit santri yang melakukan perilaku menyimpang seperti santri yang melanggar peraturan atau tata tertib pesantren.

Adapun pelanggaran yang terjadi pada santri di pondok pesantren Miftahul Huda III yaitu tidak shalat berjamaah, tidak ikut pengajian/bolos, keluar pesantren tanpa izin dari pihak pesantren, berpacaran, meminjam barang tanpa sepengetahuan pemiliknya, mencuri, dan sebagainya.
Pesantren merupakan sebuah lembaga pendidikan Islam yang berupaya untuk membina moral santri agar memiliki akhlak yang mulia dan mengamalkan ilmu agama sebagai pedoman hidup sehari-hari. Menurut Mulyani (2012, hlm. 10) menyebutkan, "Pondok pesantren adalah lembaga pendidikan non-formal yang bergerak di bidang keagamaan yang bertujuan untuk mengembangkan kemampuan masyarakat dalam memahami dan mengamalkan nilai-nilai ajaran agama Islam”.

Pondok pesantren sebagai lembaga pendidikan Islam tentunya memiliki upaya dalam membina santri yang sering melanggar tata tertib pesantren agar berperilaku sesuai dengan nilai-nilai agama Islam dan mentaati kembali norma yang berlaku di pondok pesantren tersebut. Selain itu kehidupan di pesantren juga diharapkan dapat membantu santri dalam pembentukan pribadi yang lebih baik.

Strategi yang diberikan merupakan upaya pihak pondok pesantren dalam mengatasi santri yang melakukan perilaku menyimpang. Sehingga dengan adanya upaya tersebut, santri dapat mengontrol perilakunya dan tidak melakukan perilaku menyimpang lagi. Petter L. Berger (dalam Narwoko dan Suyanto, 2007, hlm.132) menyatakan bahwa, 'Berbagai cara yang digunakan masyarakat untuk 
menertibkan anggota masyarakat yang membangkang'. Berdasarkan pernyataan tersebut, pesantren melakukan berbagai upaya untuk mengatasi santri yang menyimpang agar kembali berperilaku sesuai dengan nilai dan norma yang berlaku di pesantren.

\section{STUDI LITERATUR}

\section{1 Konsep Perilaku Menyimpang}

Perilaku menyimpang menurut Setiadi dan Kolip (2011, hlm. 187) yaitu, "Semua perilaku manusia yang dilakukan baik secara individual maupun secara kelompok tidak sesuai dengan nilai dan norma yang berlaku di dalam kelompok tersebut". Pendapat tersebut diperkuat oleh Saparinah Sadli (dalam Willis, 2014, hlm. 5) yang menyatakan, 'Mengistilahkan kelainan tingkah laku itu dengan perilaku menyimpang. Menurutnya, perilaku menyimpang adalah tingkah laku yang menyimpang dari norma-norma sosial'.

Zanden (dalam Sunarto, 2004, hlm. 176) menjelaskan bahwa, 'Penyimpangan merupakan perilaku yang oleh sejumlah besar orang dianggap sebagai hal yang tercela dan di luar batas toleransi'. Artinya bahwa perilaku yang dikategorikan menyimpang adalah perilaku tercela yang tidak sesuai dengan harapan masyarakat sehingga anggota masyarakat yang melakukan perilaku menyimpang tersebut tidak akan mendapatkan toleransi karena tindakan perilakunya yang sudah di luar batas kewajaran.

Berdasarkan pengertian di atas, maka dapat disimpulkan bahwa perilaku menyimpang adalah perilaku atau tindakan di luar kebiasaan, perilaku yang berbeda dari perilaku anggota masyarakat lain pada umumnya, dimana anggota masyarakat berperilaku tidak sesuai dengan nilai-nilai, aturan, atau norma sosial yang berlaku.

\subsection{Konsep Pengendalian Sosial}

Menurut Horton dan Hunt (1984, hlm.176) menyatakan bahwa, "Pengendalian sosial adalah sebagai cara mengarahkan rakyat untuk memerankan perannya sebagaimana yang diharapkan". Hal ini berkaitan dengan suatu cara untuk mengarahkan warganya agar dapat memerankan perannya dalam bermasyarakat untuk mencapai ketertiban sosial.

Lebih lanjut, Setiadi dan Kolip (2011, hlm.253) mengungkapkan bahwa, "Pengendalian sosial adalah cara dan proses pengawasan yang direncanakan atau tidak yang bertujuan untuk mengajak, mendidik, bahkan memaksa warga masyarakat agar mematuhi norma dan nilai sosial yang berlaku di dalam kelompoknya". Dari pendapat tersebut dapat dijelaskan bahwa pengendalian sosial merupakan sebuah cara yang dilakukan untuk mengawasi yang direncanakan maupun yang tidak direncanakan untuk mengajak, mendidik, hingga mendorong masyarakat agar mematuhi nilai dan norma yang berlaku di dalam masyarakatnya.

Sementara itu, menurut Karel J. Veeger (dalam Setiadi dan Kolip, 2011, hlm. 252) menyatakan bahwa: Pengendalian sosial sebagai titik kelanjutan dari proses sosialisasi dan berhubungan dengan cara dan metode yang digunakan untuk mendorong seseorang agar berperilaku selaras dengan kehendak kelompok atau masyarakat yang jika dijalankan secara efektif, perilaku individu akan konsisten dengan tipe perilaku yang diharapkan.

Berdasarkan uraian di atas, bahwa pengendalian sosial adalah kelanjutan dari sosialisasi yang digunakan untuk mendorong individu agar berperilaku sesuai dengan yang diharapakan di masyarakat. Dari beberapa definisi di atas, dapat disimpulkan bahwa pengendalian sosial adalah suatu cara atau proses yang dilakukan untuk mengawasi, mengajak hingga mendorong seseorang agar berperilaku selaras dengan nilai dan norma yang ada di dalam masyarakat agar tercipta suatu ketertiban sosial.

Setiadi dan Kolip (2011, hlm.255) menyatakan bahwa, "Pengendalian sosial preventif adalah segala bentuk pengendalian sosial yang berupa pencegahan atas perilaku menyimpang (deviation) agar dalam kehidupan sosial tetap kondusif (konformis)". Berdasarkan pendapat tersebut, bahwa pengendalian sosial yang bersifat preventif merupakan tindakan pencegahan untuk meminimalisir terjadinya suatu perilaku yang tidak diharapkan di dalam masyarakat agar tetap berlangsung kehidupan sosial yang tertib.

Narwoko dan Suyanto (2004, hlm. 134) menyatakan bahwa, "Kontrol sosial yang dilakukan setelah terjadi pelanggaran dengan maksud hendak memulihkan keadaan agar bisa berjalan seperti semula disebut kontrol sosial yang bersifat represif'. Dari uraian tersebut bahwa pengendalian sosial yang bersifat represif akan memberikan sanksi atau efek jera kepada individu yang melanggar norma sosial agar kembali berperilaku sesuai dengan harapan masyarakat.

\subsection{Konsep Pondok Pesantren}

Mastuhu (1994, hlm. 55) menyatakan, "Secara istilah pesantren adalah lembaga pendidikan tradisional Islam untuk mempelajari, memahami, 
mendalami, menghayati, dan mengamalkan ajaran Islam dengan menekankan pentingnya moral keagamaan sebagai pedoman perilaku sehari-hari”. Berdasarkan pendapat tersebut, dapat dijelaskan bahwa pondok pesantren merupakan sebuah lembaga pendidikan Islam untuk mendalami ajaran Islam dan mengamalkannya dalam kehidupan sehari-hari sekaligus menjadi tempat tinggal bagi santri yang menimba ilmu disana.

Seperti halnya lembaga pendidikan lain, pesantren pun tidak pernah terlepas dari beberapa elemen pembangun lainnya dalam mempertahankan perkembangannya. Adapun elemen-elemen tersebut sebagaimana dikemukakan Dhofier (1982, hlm. 44) yaitu, "Pondok, masjid, santri, pengajaran kitab Islam klasik, dan kyai". Kelima elemen tersebut merupakan unsur penting dalam mendirikan sebuah lembaga pendidikan Islam yaitu pesantren.

Sebuah pesantren sangat erat kaitannya dengan pondok, karena pondok merupakan tempat tinggal bagi santri. Selain itu, kyai pun hidup berdampingan bersama santri di pondok pesantren. Hal ini sejalan dengan pendapat Hasbullah (1999, hlm. 142) bahwa, "Definisi singkat istilah pondok adalah tempat sederhana yang merupakan tempat tinggal Kyai bersama para santrinya".

Elemen selanjutnya yaitu masjid. Masjid merupakan elemen penting dalam pembangunan pondok pesantren karena masjid merupakan tempat untuk melaksanakan ibadah lima waktu sekaligus menjadi tempat dalam proses pengajaran kitab-kitab Islam klasik.

Santri merupakan unsur penting dalam mengembangkan keberhasilan pembangunan pondok pesantren. Menurut Mahardika (2012, hlm. 30) menyatakan bahwa, "Santri merupakan unsur yang penting sekali dalam perkembangan sebuah pesantren karena langkah pertama dalam tahap-tahap membangun pesantren adalah bahwa harus ada murid yang datang untuk belajar dari seorang Alim”.

Setelah santri, elemen inti dalam pembangunan pondok pesantren yaitu adanya kyai. Menurut Mahardika (2012, hlm. 28) bahwa, "Kyai atau ustadz merupakan komponen penting yang amat menetukan keberhasilan pendidikan di pesantren. Selain itu, tidak jarang kyai atau ustadz adalah pendiri dan pemilik pesantren itu atau keluarga keturunannya". Oleh karena itu, Perkembangan pondok pesantren akan bergantung kepada figur kyai.

Elemen terakhir dalam pembangunan sebuah pondok pesantren yaitu adanya pengajaran kitab klasik. Menurut Febriansyah (2015, hlm. 42) menyatakan bahwa, "Kitab klasik merupakan sumber ajar di pondok pesantren tradisional yang berpaham pada madzhab syafi'iyyah". Kitab klasik atau kita kenal dengan sebutan kitab kuning merupakan sumber pengajaran yang terdapat di pondok pesantren mengenai agama Islam dalam berbagai bidang seperti fiqih, tauhid, dan tasawuf yang menggunakan huruf Arab gundul atau huruf Arab tanpa tanda baca dan ditulis oleh para ulama.

\section{METODE PENELITIAN}

Penelitian ini merupakan penelitian kualitatif dengan menggunakan metode studi kasus. Penelitian ini dilakukan di pondok pesantren Miftahul Huda III yang beralamt di jl. Margabakti Babakan Kertasari RT 03 RW 03 Kelurahan Margabakti Kecamatan Margabakti Kota Tasikmalaya. Alasan memilih pondok pesantren Miftahul Huda III karena di pesantren tersebut terdapat santri-santri yang melakukan berbagai bentuk perilaku menyimpang. hal ini sesuai dengan tujuan peneliti untuk mengetahui bagaimana upaya pondok pesantren dalam mengatasi santri yang berperilaku menyimpang.

Sedangkan subjek yang akan diambil dalam penelitian ini adalah pengurus pondok pesantren yang melaksanakan upaya dalam mengatasi santri yang berperilaku menyimpang, santri laki-laki dan santri perempuan, serta masyarakat di sekitar lingkungan pesantren. Pada penelitian ini, peneliti menggunakan teknik purposive sampling dalam menentukan partisipan penelitian. Adapun teknik pengumpulan data yang digunakan dalam penelitian ini adalah wawancara mendalam, observasi, dan studi dokumentasi.

\section{HASIL DAN PEMBAHASAN}

Strategi yang diberikan merupakan upaya pihak pondok pesantren dalam mengatasi santri yang melakukan perilaku menyimpang. Sehingga dengan adanya upaya tersebut, santri dapat mengontrol perilakunya dan tidak melakukan perilaku menyimpang lagi. Berdasarkan data yang diperoleh, pihak yang menangani perilaku menyimpang santri dilakukan oleh pengurus pondok pesantren. Adapun jika bentuk pelanggaran dilakukan secara berulangulang oleh santri, maka pengurus akan bekerja sama dengan dewan guru untuk menanganinya. Begitu halnya pada pelanggaran dengan kategori berat, pengurus akan melibatkan dewan guru dalam menangani santri dan memberi keputusan terkait hukuman yang diterima santri. Penanganan bagi 
santri laki-laki yang menyimpang dilakukan oleh pengurus santri laki-laki, adapun penanganan santri perempuan dilakukan oleh pengurus santri perempuan juga. Namun hal tersebut hanya berlaku bagi santri yang melakukan perilaku menyimpang pada kategori ringan. Sementara bagi santri laki-laki dan santri perempuan yang melakukan perilaku menyimpang pada kategori sedang dan berat, maka penanganannya dilakukan dengan kerjasama antara pengurus santri laki-laki dan pengurus santri perempuan.

Pihak pondok pesantren terutama pengurus selalu melakukan upaya untuk mengatasi santri yang berperilaku menyimpang. Upaya pertama yang dilakukan pesantren adalah pemberian tindakan langsung berupa teguran. Jika pengurus melihat santri yang berperilaku menyimpang, maka santri yang bersangkutan akan langsung diberikan teguran dan ancaman sanksi jika tetap melakukan penyimpangan. Teguran tersebut berlaku bagi semua santri yang melanggar, baik pelanggaran ringan, sedang, maupun berat.

Upaya selanjutnya yaitu dengan memberikan sanksi terhadap santri yang melanggar. Sanksi tersebut ditetapkan oleh pengurus dari hasil musyawarah dengan persetujuan dewan guru dan pimpinan pesantren. Sanksi berlaku bagi santri yang sekurang-kurangnya dua kali melakukan pelanggaras, kecuali bagi santri yang melakukan perilaku menyimpang pada kategori berat, setelah diberi teguran, santri yang bersangkutan langsung diberikan sanksi oleh pengurus. Adapun sanksi yang telah ditetapkan terdiri atas tiga tingkatan. Pertama, sanksi ringan diberikan kepada santri yang melakukan pelanggaran ringan. Sanksi tersebut berupa pemanggilan santri ke ruang pengurus, kemudian santri diberikan nasihat-nasihat dan motivasi mengenai pentingnya memiliki akhlak yang mulia. Adapun bagi santri yang keluar pesantren tanpa seizin pengurus dan santri yang pulang ke rumah lebih dari batas waktu yang ditetapkan akan diberikan hukuman lain seperti membersihkan toilet, membersihkan halaman komplek pesantren, dan membersihkan asrama. Dengan adanya hukuman tersebut, diharapakan dapat menumbuhkan sikap rajin dalam diri santri.

Berbeda halnya dengan santri laki-laki yang melakukan pelanggaran ringan seperti tidak shalat berjamaah dan tidak mengikuti pengajian, santri tersebut akan diberikan hukuman langsung dengan cara dicambuk oleh dewan guru di depan kelas. Hal itu terjadi karena santri tersebut tidak menunjukkan perubahan perilaku setelah diberikan sanksi oleh pengurus dan karena intensitas perilaku menyimpang yang dilakukannya.

Kedua, sanksi sedang diberikan kepada santri yang melakukan pelanggaran pada kategori sedang.
Santri yang melakukan pelanggaran sedang akan diberikan sanksi berupa pemberian nasihat di depan semua santri dan membacakan kesalahan yang telah dilakukannya. Sebelum membacakan kesalahannya, santri tersebut disuruh menulis terlebih dahulu mengenai kesalahan atau pelanggaran yang telah dilakukannya. Tujuan pemberian sanksi tersebut agar santri merasa malu atas kesalahan yang telah dilakukan dan menyadarkan santri bahwa perilaku yang ia lakukan telah melanggar aturan nilai dan norma yang berlaku di pesantren.

Ketiga, sanksi berat akan diberikan kepada santri yang melakukan pelanggaran pada kategori berat. Sanksi tersebut yaitu dengan membacakan kesalahannya di depan semua santri, pengurus, serta dewan guru kemudian santri tersebut langsung dikeluarkan secara tidak terhormat dan tidak diperbolehkan lagi kembali ke pesantren. Hukuman tersebut berlaku bagi santri yang telah merusak citra dan nama baik pesantren. Adapun bagi santri yang berkhalwat atau berduaan dengan lawan jenis yang bukan muhrim, maka santri yang bersangkutan masih akan diberikan kesempatan untuk menetap di pesantren dengan syarat melakukan perjanjian bahwa ia tidak akan mengulangi perilaku yang melanggar nilai dan norma tersebut. Perjanjian dibacakan di depan semua santri, pengurus, dan dewan guru. Namun, jika mengingkari perjanjian tersebut, maka santri tetap akan dikeluarkan dan tidak diperbolehkan lagi kembali ke pesantren Miftahul Huda III.

Adapun selain sanksi yang telah dijelaskan, santri yang melanggar peraturan akan dikenakan denda. Namun, denda tersebut hanya berlaku untuk pelanggaran-pelanggaran tertentu. Pihak pesantren juga melakukan kerja sama dengan masyarakat dalam mengatasi santri yang berperilaku menyimpang. Pihak pesantren terutama dewan guru selalu berpesan kepada masyarakat untuk memberikan teguran dan nasihat secara langsung jika terdapat santri yang melakukan perilaku menyimpang di lingkungan masyarakat kemudian melaporkan perilaku santri yang bersangkutan ke pihak pesantren untuk ditindaklanjuti.

Petter L. Berger (dalam Narwoko dan Suyanto, 2007, hlm.132) menyatakan bahwa, 'Berbagai cara yang digunakan masyarakat untuk menertibkan anggota masyarakat yang membangkang'. Berdasarkan pernyataan tersebut, pesantren melakukan berbagai upaya untuk mengatasi santri yang menyimpang agar kembali berperilaku sesuai dengan nilai dan norma yang berlaku di pesantren. Dalam hal ini, peneliti lebih memfokuskan kepada upaya yang bersifat represif. Narwoko dan Suyanto (2004, hlm. 134) menyatakan bahwa, "Kontrol sosial yang dilakukan setelah terjadi pelanggaran dengan maksud hendak memulihkan keadaan agar bisa 
berjalan seperti semula disebut kontrol sosial yang bersifat represif'.

Upaya pertama yang dilakukan pesantren adalah pemberian tindakan langsung berupa teguran. Jika pengurus melihat santri yang berperilaku menyimpang, maka santri yang bersangkutan akan langsung diberikan teguran dan ancaman sanksi jika tetap melakukan penyimpangan. Teguran tersebut berlaku bagi semua santri yang melanggar, baik pelanggaran ringan, sedang, maupun berat.

Upaya selanjutnya adalah dengan memberikan sanksi terhadap santri yang melanggar. Menurut Setiadi dan Kolip (2011, hlm. 257) menyatakan, "Sanksi merupakan bentuk penderitaan, kerugian, beban berat yang sengaja diciptakan oleh lembaga sosial untuk memaksa anggota masyarakat agar taat pada norma yang ada". Berdasarkan pernyataan tersebut, bahwa sanksi diciptakan untuk memaksa pelanggar agar kembali mematuhi norma yang berlaku.

Adapun sanksi yang telah ditetapkan terdiri atas tiga tingkatan. Pertama, sanksi ringan diberikan kepada santri yang melakukan pelanggaran ringan. Sanksi tersebut berupa pemanggilan santri oleh pengurus untuk kemudian diberikan nasihat dan motivasi-motivasi mengenai pentingnya memiliki akhlak yang mulia. Adapun bagi santri yang keluar pesantren tanpa seizin pengurus dan santri yang pulang ke rumah lebih dari batas waktu yang ditetapkan akan diberikan hukuman lain seperti membersihkan toilet, membersihkan halaman komplek pesantren, dan membersihkan asrama. Hukuman yang diberikan pun tetap mendidik. Dengan adanya hukuman tersebut, diharapakan dapat menumbuhkan sikap rajin dalam diri santri. Berbeda halnya dengan santri laki-laki yang melakukan pelanggaran ringan seperti tidak shalat berjamaah dan tidak mengikuti pengajian, santri tersebut akan diberikan hukuman langsung dengan cara dicambuk oleh dewan guru di depan kelas ketika kegiatan belajar mengajar. Muhammad (dalam Mugiono, 2016, hlm. 112) menyatakan, 'Hukuman bertingkat-tingkat, mulai dari pandangan yang mempunyai arti hingga hukuman berupa pukulan'. Perilaku dewan guru yang memberikan hukuman fisik kepada santri tersebut dilakukan karena tidak ada cara lain dalam menangani santri yang menyimpang dan tidak jera dengan hukuman yang diberikan.

Kedua, sanksi sedang diberikan kepada santri yang melakukan pelnggaran pada kategori sedang. Santri yang melakukan pelanggaran sedang akan diberikan sanksi berupa pemberian nasihat di depan semua santri dan membacakan kesalahan yang telah dilakukannya. Dari data tersebut, bahwa sanksi pada kategori sedang lebih menitikberatkan pada sanksi psikologis. Narwoko dan Suyanto (2004, hlm. 136) menyatakan bahwa, "Sanksi psikologis merupakan beban penderitaan yang dikenakan pada pihak yang terbebani sanksi dengan beban kejiwaan, seperti dipermalukan di muka umum". Dengan adanya sanksi tersebut, santri akan menanggung malu dan menanggung aib karena telah melanggar peraturan tata tertib pesantren. Ketiga, sanksi berat akan diberikan kepada santri yang melakukan pelanggaran pada kategori berat. Sanksi tersebut yaitu dengan membacakan kesalahannya di depan semua santri, pengurus, serta dewan guru kemudian santri tersebut dikeluarkan secara tidak terhormat dari pesantren. Sama hal nya dengan sanksi sedang, sanksi yang berat pun lebih menggunakan sanksi psikologis didalam usaha untuk menciptakan keteraturan sosial. Hal tersebut senada dengan jurnal dari Rahmawati (2013, hlm. 312) yang menyatakan, "Jika ada yang melanggar maka akan dikenakan sanksi sesuai dengan pelanggaran yang dilakukannya berat, sedang atau ringan".

Upaya selanjutnya yaitu dikenakan denda bagi santri yang melanggar baik santri yang melanggar pada kategori ringan, sedang, maupun berat. Setiadi dan Kolip (2011, hlm. 257) menyatakan bahwa, "Sanksi ekonomik merupakan beban penderitaan yang dikenakan kepada pelanggar norma berupa pengurangan benda dalam bentuk penyitaan dan denda, membayar ganti rugi, dan sebagainya". Berdasarkan pendapat tersebut, bahwa denda yang diberlakukan oleh pihak pesantren termasuk kedalam sanksi ekonomik.

Pihak pesantren juga melakukan kerja sama dengan masyarakat dalam mengatasi santri yang berperilaku menyimpang. Pihak pesantren terutama dewan guru selalu berpesan kepada masyarakat untuk memberikan teguran dan nasihat secara langsung jika terdapat santri yang melakukan perilaku menyimpang di lingkungan masyarakat kemudian melaporkan perilaku santri yang bersangkutan ke pihak pesantren untuk ditindaklanjuti.

Merujuk pada jurnal dari Siti Muhibah Zainatun tahun 2016 dengan Judul "Upaya Pengendalian Santri di Pondok Pesantren Al Luqmaniyyah" bahwa pengendalian yang dilakukan pondok pesantren $\mathrm{Al}$ Luqmaniyyah ada empat yaitu: (1) pengendalian sosial preventif, (2) pengendalian sosial represif, (3) pengendalian sosial persuasif, (4) pengendalian sosial koersif. Bentuk pengendalian tersebut dilakukan oleh tokoh pengendali sosial atau pengamat bertingkat yaitu pengasuh, ustadz dan kamtib. Pada jurnal tersebut, terdapat perbedaan dengan penelitian yang dilakukan oleh peneliti, yaitu dalam bentuk upaya pengendalian yang dilakukan. Upaya yang dilakukan pihak pesantren Miftahul Huda III hanya pengendalian yang bersifat preventif dan represif saja. Adapun persamaannya yaitu pihak 
yang melakukan upaya dalam mengatasi santri berperilaku menyimpang.

\section{KESIMPULAN}

Strategi yang diberikan merupakan upaya pihak pondok pesantren dalam mengatasi santri yang melakukan perilaku menyimpang. Sehingga dengan adanya upaya tersebut, diharapkan santri dapat mengontrol perilakunya dan tidak melakukan perilaku menyimpang lagi. Upaya pertama yang dilakukan pesantren adalah pemberian tindakan langsung berupa teguran. Jika pengurus melihat santri yang berperilaku menyimpang, maka santri yang bersangkutan akan langsung diberikan teguran dan ancaman sanksi jika tetap melakukan penyimpangan. Upaya selanjutnya adalah memberikan hukuman sanksi sesuai dengan perilaku melanggar yang telah dilakukannya. Sanksi yang ditetapkan terdiri dari sanksi ringan, sanksi sedang, dan sanksi berat. Selain sanksi, pesantren juga mengenakan denda bagi santri yang melakukan pelanggaran-pelanggaran tertentu. Pihak pesantren juga melakukan kerja sama dengan masyarakat dalam mengatasi santri yang berperilaku menyimpang. Pihak pesantren terutama dewan guru selalu berpesan kepada masyarakat untuk memberikan teguran dan nasihat secara langsung jika terdapat santri yang melakukan perilaku menyimpang di lingkungan masyarakat kemudian melaporkan perilaku santri yang bersangkutan ke pihak pesantren untuk ditindaklanjuti.

\section{REFERENSI}

Febriansyah, Yogi S. (2015). Pola Adaptasi Sosial Budaya Kehidupan Santri Pondok Pesantren Nurul Barokah. Skripsi. Bandung: Universitas Pendidikan Indonesia

Hasbullah. (1999). Kapita Selekta Pendidikan Islam. Jakarta: Raja Grafindo

Mahardika, Sandika. (2012). Penerapan Metode Sorogan dalam Memahami Kitab Kuning di Pesantren Salafiyyah. Skripsi. Universitas Pendidikan Indonesia. Bandung: Tidak diterbitkan

Mastuhu. (1994). Dinamika Sistem Pendidikan Islam. Jakarta: Inis

Narwoko, J dan Suyanto, B. (2004). Sosiologi Teks Pengantar dan Terapan. Jakarta: Kencana Prenada Media Group
Rahmawati, Ida. (2013). Pola Pembinaan Santri dalam Mengendalikan Perilaku Menyimpang di Pondok Pesantren Sabilul Muttaqin Desa Kalipuro Kecamatan Pungging Mojokerto. Dalam Jurnal Kajian Moral dan Kewarganegaraan Vol. 1, No. 1

Setiadi, E dan Kolip, U. (2011). Pengantar Sosiologi. Jakarta: Kencana Prenada Media Group

Sunarto, Kamanto. (2004). Pengantar Sosiologi (Edisi Revisi). Lembaga Penerbit FE UI

Willis, S.S. (2014). Remaja dan Masalahnya; Mengupas Berbagai Bentuk Kenakalan Remaja, Narkoba, Free Sex, dan Pemecahannya. Bandung: Alfabeta

Zainatun, S. (2016). Upaya Pengendalian Santri di Pondok Pesantren Al Luqmaniyyah. Dalam Jurnal Vol 5 No 1 